\title{
Crossed Immunoelectrophoresis of Membrane Proteins from Acholeplasma laidlawii and Spiroplasma citri
}

\author{
HENRI WROBLEWSKI, KARL-ERIK JOHANSSON, AND RENEE BURLOT
}

Laboratoire de Biologie Cellulaire, Faculté des Sciences Biologiques, Complexe de Beaulieu, 35031 Rennes Cédex, France; and The Membrane Group, Institute of Biochemistry, Biomedical Center, University of Uppsala, S-751 23 Uppsala, Sweden

\begin{abstract}
Cell membranes from the two mycoplasmas Acholeplasma laidlawii and Spiroplasma citri differ greatly in solubility properties and were, therefore, used as models in this investigation. The membranes were isolated and solubilized with different neutral and anionic detergents. The solutions were analyzed by crossed immunoelectrophoresis in the presence of the corresponding detergent. In the case of $A$. laidlawii membranes, good results were obtained with the anionic detergent sodium deoxycholate (DOC) and with the neutral detergents Triton X-100 and Tween 20 . However, in the case of S. citri membranes, reliable results were obtained only with DOC. These findings indicate that it is preferable to use DOC as solubilizing agent in a standardized procedure of analyzing membrane antigens from different mycoplasmas by crossed immunoelectrophoresis. In experiments with membrane antigens from one mycoplasma and membrane antiserum from another mycoplasma, in order to save time and antisera it is recommended first to run a double diffusion and, if the result is positive, the sample can be further analyzed by crossed immunoelectrophoresis.
\end{abstract}

Growth inhibition tests (9), metabolism inhibition tests (32), and immunofluorescence tests (8) are the techniques most used for classifying and identifying mycoplasmas. Methods not based on serology have also been used, e.g., polyacrylamide gel electrophoresis of cell proteins (29) and membrane proteins (31) and determination of the size (2) and base composition (24) of the genome.

Immunochemical gel precipitation techniques are widely used as powerful analytical tools in biochemistry and microbiology. In the field of mycoplasma taxonomy, the use of these techniques also seems very promising. The first significant results were obtained by immunodiffusion $(1,14,17,18,20,26,33)$ and by immunoelectrophoresis (1). More recently, crossed immunoelectrophoresis (19) was successfully used to study either total protein compositions of mycoplasma cells (34) or protein compositions of mycoplasma membranes $(16,36,37)$.

The purpose of the present work was to standardize the crossed immunoelectrophoresis technique for accurate analysis of the protein composition of any mycoplasma membrane. Such a method should be very useful for the classification and rapid identification of mycoplasmas. Since intrinsic membrane proteins are amphiphilic, it is necessary to use detergents for solubilization and to prevent aggregation in crossed immunoelectrophoresis. The main problem in the standardization was, in fact, choosing the appropriate detergent. Acholeplasma laidlawii and Spiroplasma citri were used as models in this work. The membranes of the former are unusually soluble in many detergents, whereas the membranes of the latter are poorly soluble in several of the detergents commonly used for crossed immunoelectrophoresis of membrane proteins.

\section{MATERIALS AND METHODS}

Organisms. The two species of mycoplasmas used in this work were $S$. citri (strain C189 ATCC 27665) and A. laidlawii (strain A PG18 ATCC 23206).

Growth of cells. A. laidlawii was grown at $37^{\circ} \mathrm{C}$ as described by Razin et al. (28) and $S$. citri was grown at $32^{\circ} \mathrm{C}$ as described previously (36). The cells were harvested from the liquid media during their late logarithmic growth phase by centrifugation at $15,000 \times g$ for $30 \mathrm{~min}$ at $4^{\circ} \mathrm{C}$.

Preparation of cell membranes. The cells of both organisms were lysed by osmotic shock (28), and the membranes were recovered by centrifugation at $38,000 \times g$ for $1 \mathrm{~h}$ at $4^{\circ} \mathrm{C}$. They were then washed four times with diluted $\beta$-buffer (28). The $S$. citri membranes were treated with deoxyribonuclease prior to the washing (27). The membranes were finally washed once with distilled water and freezedried.

Membrane solubilization. The membranes were solubilized with the detergents essentially as described previously (13). One milliliter of a membrane suspension containing $20 \mathrm{mg}$ of membrane protein was mixed with $1 \mathrm{ml}$ of the detergent solution. Six different detergents were used in this 
study: the ionic detergents sodium dodecyl sulfate (SDS), sodium deoxycholate (DOC), and Sarkosyl (sodium lauryl-sarcosinate), and the neutral detergents Triton X-100 (polyoxyethylene p-tert-octyl phenol), Tween 20 (polyoxyethylene sorbitan monolaurate), and Brij 58 (polyoxyethylene-20-cetylether). The concentrations of the detergents and their molecular weights are given in Table 1 . The different mixtures were centrifuged at $180,000 \times g$ for $1 \mathrm{~h}$ at $5^{\circ} \mathrm{C}$ to remove insoluble materials (15).

Preparation of antisera. Rabbits were immunized by subcutaneous injections with a suspension of unfractionated membranes mixed with Freund adjuvant as described in a previous paper (36). Three rabbits were inoculated with $A$. laidlawii membranes and three rabbits were inoculated with $S$. citri membranes. The production of antibodies was checked weekly by crossed immunoelectrophoresis experiments after the fourth inoculation.

Crossed immunoelectrophoresis. The protein compositions of the samples were determined by crossed immunoelectrophoresis $(5,19)$. The technique was modified by the introduction of a detergent into the agarose gel to prevent the precipitation of the amphiphilic membrane proteins $(3,16)$. A 1$\mathrm{mm}$-thick gel was cast on plates $(85$ by $100 \mathrm{~mm})$. The concentrations of the detergents in the gels are given in Table 1. The electrophoresis experiments in the first and the second directions were run at 5 and $18^{\circ} \mathrm{C}$, respectively. Other experimental conditions are given in Table 2. After the completion of the

TABLE 1. Concentrations in the sample $\left(C_{s}\right)$ and in the gel $\left(C_{g}\right)$ of the different detergents used in crossed immunoelectrophoresis

\begin{tabular}{|c|c|c|c|c|c|}
\hline \multirow[b]{2}{*}{ Detergent } & \multirow[b]{2}{*}{ Mol wt } & \multicolumn{2}{|c|}{$\mathrm{C}_{\mathrm{s}}$} & \multicolumn{2}{|c|}{$\mathrm{C}_{\mathrm{g}}$} \\
\hline & & $\mathrm{mM}$ & $\begin{array}{c}\% \\
\text { (wt/ } \\
\text { vol) }\end{array}$ & $\mathrm{mM}$ & $\begin{array}{c}\% \\
\text { (wt/ } \\
\text { vol) }\end{array}$ \\
\hline SDS & 288.4 & 100 & 2.9 & 17 & 0.5 \\
\hline DOC & 414.6 & 100 & 4.1 & 13 & 0.5 \\
\hline Sarkosyl & 293.4 & 100 & 2.9 & 17 & 0.5 \\
\hline Triton X-100 & 646.60 & 46 & 3.0 & 15 & 1.0 \\
\hline Tween 20 & $1,230^{a}$ & $24^{b}$ & 3.0 & $8^{b}$ & 1.0 \\
\hline Brij 58 & $?$ & ? & 3.0 & $?$ & 1.0 \\
\hline
\end{tabular}

a The average molecular weight.

${ }^{b}$ Based on the average molecular weight.

TABLE 2. Experimental conditions for crossed immunoelectrophoresis

\begin{tabular}{lccccc}
\hline \multirow{2}{*}{ Detergent } & \multicolumn{2}{c}{ First direction } & & \multicolumn{2}{c}{ Second direction } \\
\cline { 2 - 3 } \cline { 5 - 6 } & $\begin{array}{c}\text { Current } \\
(\mathrm{mA} / \\
\text { plate) }\end{array}$ & Time (h) & $\begin{array}{c}\text { Current } \\
(\mathrm{mA} / \\
\text { plate) }\end{array}$ & Time (h) \\
\hline SDS & 10 & 2 & 2 & 18 \\
DOC & 15 & 2 & & 4 & 18 \\
Sarkosyl & 10 & 2 & & 2 & 18 \\
Triton X-100 & 20 & 2.5 & 5 & 18 \\
Tween 20 & 20 & 2.5 & & 5 & 18 \\
Brij 58 & 20 & 2.5 & 5 & 18 \\
\hline
\end{tabular}

crossed immunoelectrophoresis, the plates were incubated for $24 \mathrm{~h}$ at $30^{\circ} \mathrm{C}$ in a moist chamber. They were subsequently soaked for $48 \mathrm{~h}$ in $0.15 \mathrm{M} \mathrm{NaCl}$ at $5^{\circ} \mathrm{C}$ and for $1 \mathrm{~h}$ in distilled water at $20^{\circ} \mathrm{C}$. The gels were finally dehydrated and stained with amido black $10 \mathrm{~B}$.

Protein estimation. The protein concentration of the membrane suspension was determined by the procedure of Lowry et al. (22) after the dissolution of the membranes by SDS. Crystalline serum albumin was used as a standard.

Chemicals. DOC and Triton X-100 were purchased from E. Merck AG (Darmstadt, Germany), and SDS, Sarkosyl, Tween 20, and Brij 58 were from Sigma Chemical Co., St. Louis, Mo.

\section{RESULTS}

All of the results are summarized in Table 3. The precipitation lines, which were so faint that they could be discerned only with difficulty on the plates and photographs, will be called minor peaks in contrast to major ones.

Experiments with SDS. When SDS was used in crossed immunoelectrophoresis, it was possible to get precipitation lines only when the detergent was omitted from the second direction. The result was, however, not very good, as can be seen from Fig. 1a and b. All precipitation lines appeared at approximately the same distance from the starting position of the first direction and they were incomplete. These results, which were found for both $A$. laidlawii membranes and $S$. citri membranes, show that SDS is an unsuitable detergent in crossed immunoelectrophoresis. The observations can be explained by the properties of SDS and those of the agarose gel. All proteins are capable of binding large amounts of SDS (30). This binding induces a denaturation of the proteins and they get the same surface charge density (30).

TABLE 3. Number of precipitation lines obtained by crossed immunoelectrophoresis of A. laidlawii and

$S$. citri membrane proteins in the presence of different detergents

\begin{tabular}{|c|c|c|c|c|c|c|}
\hline \multirow{3}{*}{ Detergent } & \multicolumn{6}{|c|}{ No. of precipitation lines } \\
\hline & \multicolumn{3}{|c|}{$\begin{array}{l}\text { A. laidlawii mem- } \\
\text { brane }\end{array}$} & \multicolumn{3}{|c|}{ S. citri membrane } \\
\hline & $\mathrm{m}^{a}$ & $\mathbf{M}^{b}$ & $\mathrm{~T}^{c}$ & $\mathrm{~m}$ & $\mathbf{M}$ & $\mathrm{T}$ \\
\hline SDS & $?^{d}$ & $?$ & $?$ & $?$ & $?$ & $?$ \\
\hline DOC & 4 & 12 & 16 & 3 & 10 & 13 \\
\hline Sarkosyl & 5 & 8 & 13 & 3 & 3 & 6 \\
\hline Triton X-100 & 5 & 10 & 15 & 1 & 2 & 3 \\
\hline Tween 20 & 5 & 10 & 15 & 4 & 4 & 8 \\
\hline Brij 58 & 2 & 6 & 8 & 3 & 5 & 8 \\
\hline
\end{tabular}

a Minor peaks.

${ }^{b}$ Major peaks.

c Total precipitation lines $(m+M)$.

${ }^{d}$ ?, Impossible to estimate. 
Thus, it is impossible to separate them by electrophoresis in an agarose gel, since this gel is nonsieving and the proteins are mainly separated by their surface charge density. The antigen-antibody reactions are inhibited by the denaturation of antigenic proteins by SDS, and also because of the denaturation and migration of immunoglobulins. Like any proteins, immunoglobulins will bind SDS if the detergent is also introduced into the second direction of the crossed immunoelectrophoresis.

Experiments with DOC. In the presence of DOC in the two directions of the crossed immunoelectrophoresis, it was possible to detect up to 16 precipitation lines (12 major and 4 minor peaks) with $A$. laidlawii membrane proteins, and up to 13 precipitation lines (10 major and 3 minor peaks) with $S$. citri membrane proteins (Fig. 1c and d).

Although DOC is an ionic detergent, it is mainly bound to intrinsic membrane proteins, usually without denaturation $(11,12,23)$. The antigenic structure of the proteins is preserved in the presence of this detergent, allowing the formation of antigen-antibody complexes. The binding of DOC leads, however, to the addition of negative charges $\left(-\mathrm{COO}^{-}\right)$to the surfaces of the proteins. The consequence will be a decreased relative difference in electrophoretic migration rate between the membrane proteins in agarose gels. This difference reflects, besides the surface charge of the native proteins, the different amounts of DOC bound by each protein.

Experiments with Sarkosyl. The results obtained in the presence of Sarkosyl were rather similar to those obtained with DOC in the case of $A$. laidlawii membrane proteins. It was possible to detect up to 13 precipitation lines (8 major and 5 minor peaks) with, in the first direction, a small difference in electrophoretic rate of migration for the majority of the proteins (Fig. 1e). The results were, however, not so satisfactory with $S$. citri membranes (Fig. $1 \mathrm{f}$ ), since only 6 precipitation lines ( 3 major and 3 minor peaks) were observed.

Experiments with Triton $\mathrm{X}-100$ and Tween 20. The immunoelectropherogram obtained with $A$. laidlawii membrane proteins in the presence of Triton X-100 was very similar to the one obtained in the presence of Tween 20 (Fig. $2 a$ and $c)$. In both experiments 15 precipitation lines (10 major and 5 minor peaks) were obtained. These results are analogous to those reported by Johansson and Hjertén (16). All these data are consistent with the properties of nonionic detergents, which are usually mild and non-denaturing, and bind to intrinsic membrane proteins only $(11,12)$. Since the neu- tral detergents only bind to the hydrophobic surfaces of these proteins, the protein-detergent complex will retain some of the surface charge of the protein and the precipitation lines will be well separated.

The precipitation lines obtained with $S$. citri membrane proteins were unexpectedly few and faint (Fig. 2b and d). This observation indicates that these proteins are poorly soluble in these two detergents, which has also been confirmed by measuring the ultraviolet absorbances of these solutions.

Experiments with Brij 58. Eight precipitation lines ( 6 major and 2 minor peaks) were detected with $A$. laidlawii membrane proteins in the presence of Brij 58 (Fig. 2e). The precipitation pattern obtained was, nevertheless, not accurate for analytical purposes because of the fusions occurring between several of the precipitation lines. This phenomenon indicates either incomplete dissolution of some components or proteolytic digestion of some of them during the solubilization. Incomplete dissolution might result in the fusion of some peaks due to the existence of different protein complexes containing at least one common antigen (partial identity). The other hypothesis cannot be excluded either, since proteolytic enzymes have been reported in mycoplasma membranes (4).

The results obtained with Brij 58 on $S$. citri membrane proteins, i.e., 8 precipitation lines, 3 of which were major and 5 minor peaks (Fig. $2 \mathrm{f}$, were similar to those obtained with the two other neutral detergents. Thus, Brij 58 was also inefficient in solubilizing the $S$. citri membrane proteins.

\section{DISCUSSION}

As pointed out previously (37), the application of the crossed immunoelectrophoresis technique to analyze membrane proteins often involves a compromise. The problem is to find a detergent as powerful as possible to solubilize a maximum of membrane proteins, but as mild (i.e., non-denaturing) as possible to avoid denaturing them. The anionic detergent SDS is the most powerful for membrane solubilization but it is, unfortunately, highly denaturing $(11,12)$ and therefore not very useful for crossed immunoelectrophoresis of proteins. Nonionic detergents, on the other hand, are mild, i.e., nondenaturing $(11,12)$; especially Tween 20 (16), Berol EMU-043 (3), and Triton X-100 (21) often solubilize membrane proteins selectively (13, 21,38 ) and give good results in crossed immunoelectrophoresis $(3,16,25)$. They were, however (at least the three nonionic detergents used in this work), unable to solubilize $S$. citri membrane proteins efficiently enough. The 

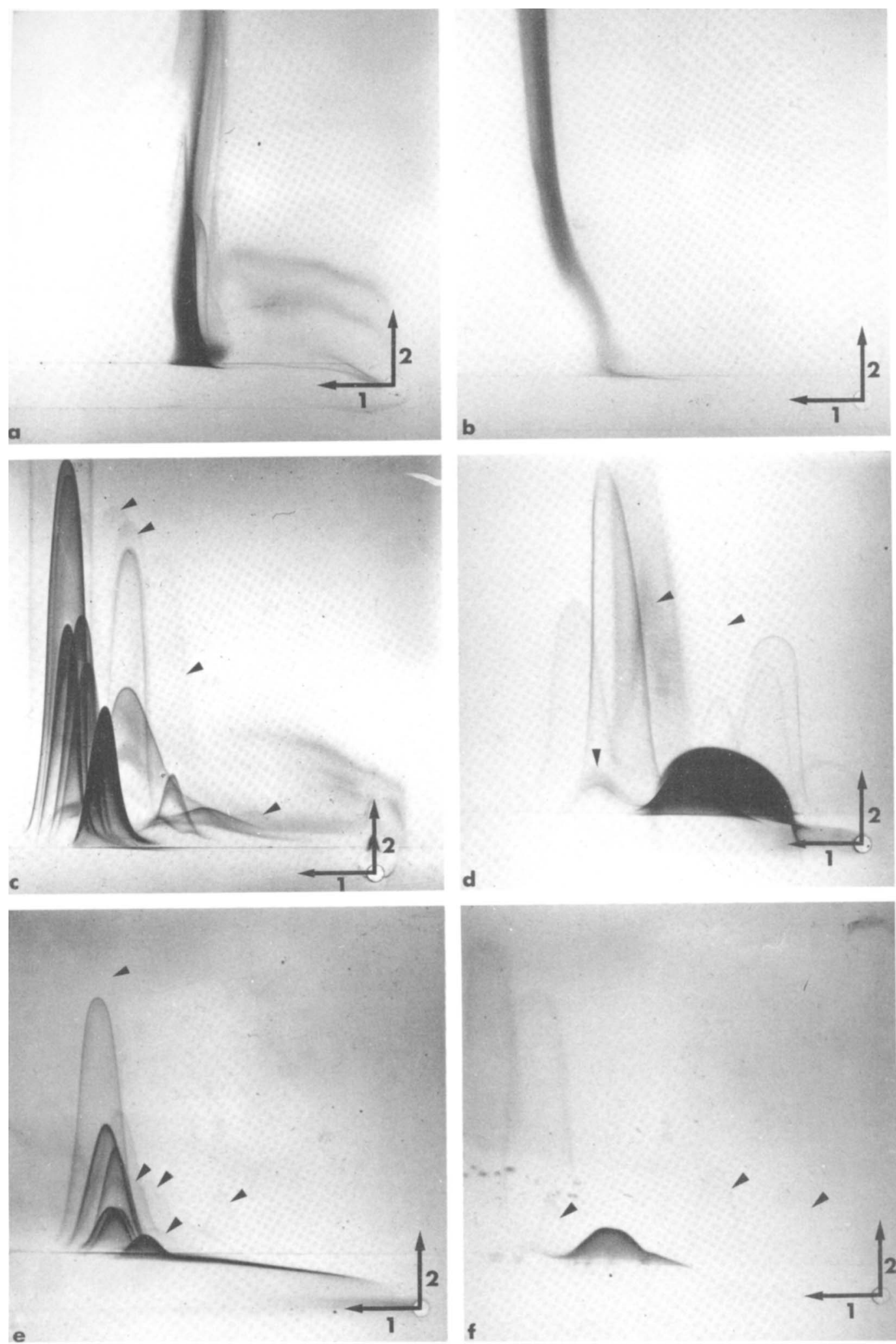

FIG. 1. Crossed immunoelectrophoresis of membrane proteins in the presence of ionic detergents. A. laidlawii membrane proteins: electrophoresis in SDS (a), DOC (c), and Sarkosyl (e). S. citri membrane proteins: electrophoresis in SDS $(b), D O C(d)$, and Sarkosyl $(f)$. The faint precipitation lines close to the sample well correspond to incompletely solubilized material which remains in the supernatant even after centrifugation at 180,000 $\times$ g. It was possible to solubilize the material completely by adding detergent in excess to the sample after the centrifugation. The arrows indicate the faintest precipitation lines (minor peaks). 

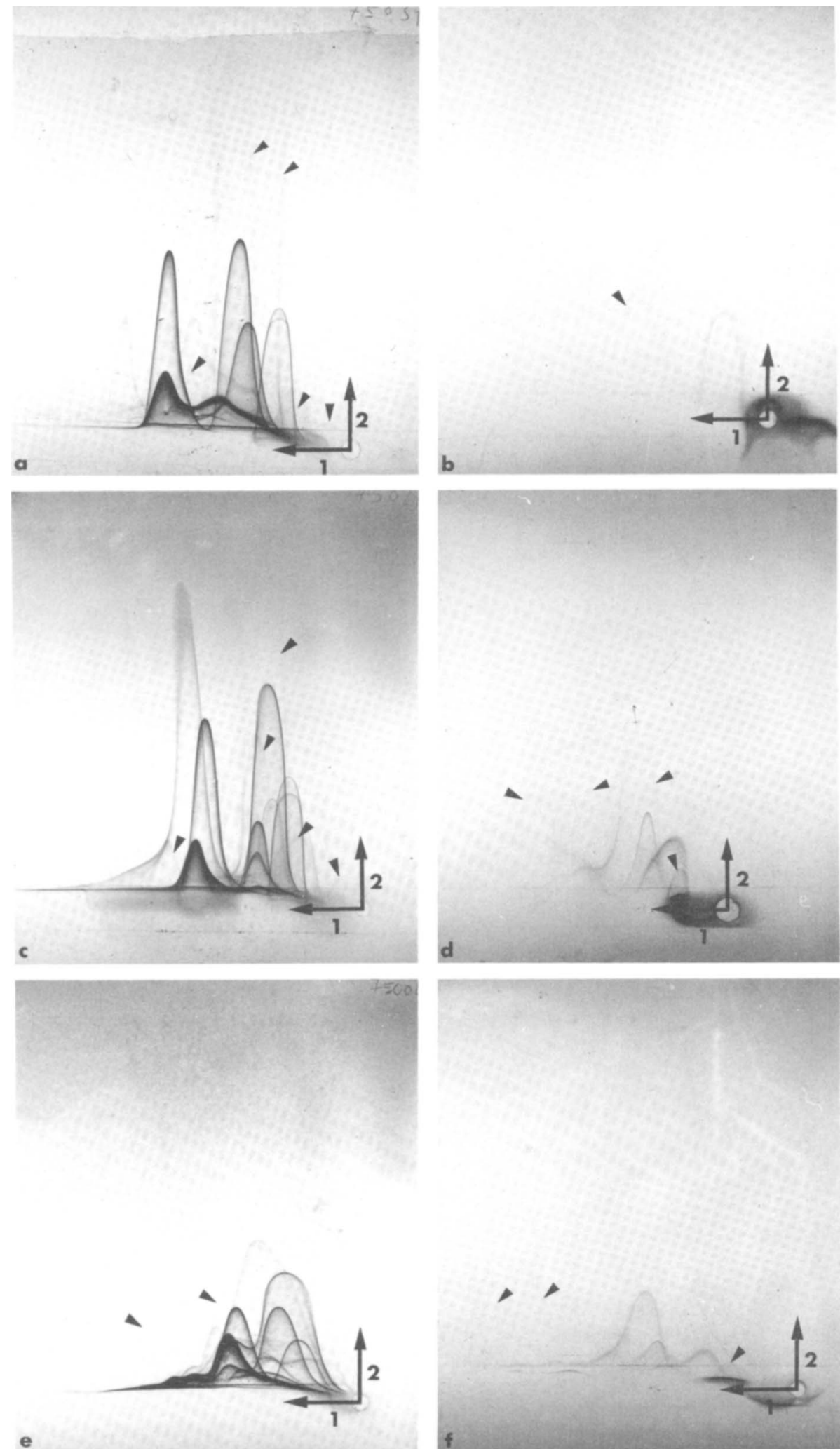

FIG. 2. Crossed immunoelectrophoresis of membrane proteins in the presence of nonionic detergents. A. laidlawii membrane proteins: electrophoresis in Triton X-100 (a), Tween $20(\mathrm{c})$, and Brij $58(\mathrm{e})$. S. citri membrane proteins: electrophoresis in Triton X-100 (b), Tween $20(d)$, and Brij $58(f)$. The arrows indicate the faintest precipitation lines. 
best results were obtained with DOC, which, although anionic, is mild and non-denaturing $(11,12,23)$. This detergent gave the most accurate results in crossed immunoelectrophoresis of $S$. citri membrane proteins. Since DOC also gave reliable results with $A$. laidlawii membranes, it is recommended for crossed immunoelectrophoresis of mycoplasma membrane proteins when the aim is to standardize the procedure. Sarkosyl, the third ionic detergent that we used, gave with A. laidlawii membranes results similar to those obtained with DOC. It gave, however, much less accurate results in crossed immunoelectrophoresis of $S$. citri membrane proteins. Although Sarkosyl has already been used in the field of membrane research $(10,35)$, little is known about the interaction between this detergent and proteins. Since qualitatively similar results were obtained for A. laidlawii and S. citri membranes by crossed immunoelectrophoresis in the presence of this detergent and DOC, Sarkosyl should be considered a non-denaturing detergent, which is probably bound only by amphiphilic proteins. This hypothesis was confirmed by studying the effect of Sarkosyl on the reduced nicotinamide adenine dinucleotide dehydrogenase of $A$. laidlawii membranes. The enzyme was found to be highly active after treatment with Sarkosyl overnight as it also is in DOC. Treatment with SDS under the same conditions completely abolished the activity of this enzyme.

All these results are in agreement with those obtained by Bjerrum and Lundahl (3) on the erythrocyte membrane proteins except that, in their experiments, DOC was less useful than the nonionic detergents. This discrepancy may be explained by the affinity of the antibodies for their antigens. Since, in rabbits, it is probably more difficult to raise antibodies against human erythrocyte membranes than against microbial membranes, antibodies against erythrocyte membrane proteins may have a comparatively low affinity and their interaction with the antigens may be partially inhibited by DOC.

When systematic analyses (e.g., for a taxonomic purpose) are dealt with, the technique which is used must be not only sensitive and reproducible, but also easy to handle. Crossed immunoelectrophoresis is a very sensitive and rather simple technique, giving easily reproducible results. Nevertheless, compared to the less sensitive technique of double immunodiffusion, it has two drawbacks: it requires much more serum and it is rather time-consuming. We consequently suggest the following procedure, which saves time and sera, and which also permits an accurate analysis of the antigens. In a first step, homologous and heterologous immunoreactions are performed by double immunodiffusion. In a second step, all homologous reactions, but only immunodiffusion-positive heterologous ones, are performed by crossed immunoelectrophoresis, since, anyway, immunodiffusion-negative heterologous experiments would give negative results in crossed immunoelectrophoresis. This strategy is valuable not only for the analysis of membrane proteins, but also for any antigens.

\section{ACKNOWLEDGMENTS}

We thank Stellan Hjertén for constructive criticism and Anne-Marie Touzalin and Bernard Morille for skillful technical assistance.

This work was supported financially by the Centre National de la Recherche Scientifique (LA no. 256, Contrat C.N.R.S.-Université), by the Swedish Natural Science Research Council, the Wallenberg Foundation, the Foundation of Ollie and Elof Ericsson, and the von Kantzow Foundation.

\section{REPRINT REQUESTS}

Address reprint requests to: Dr. Henri Wróblewski, Laboratoire de Biologie Cellulaire, Faculté des Sciences Biologiques, Complexe de Beaulieu, B.P. 25 A, 35031 Rennes Cédex, France.

\section{LITERATURE CITED}

1. Argaman, M., and S. Razin. 1969. Antigenic properties of Mycoplasma organisms and membranes. J. Gen. Microbiol. 55:45-58.

2. Back, A. L., F. T. Black, C. Christiansen, and E. A. Freundt. 1969. Genome size of mycoplasmal DNA. Nature (London) 224:1209-1210.

3. Bjerrum, O. J., and P. Lundahl. 1974. Crossed immunoelectrophoresis of human erythrocyte membrane proteins. Immunoprecipitation patterns for fresh and stored samples of membranes extensively solubilized with non-ionic detergents. Biochem. Biophys. Acta 342:69-80.

4. Choules, G. L., and W. R. Gray. 1971. Peptidase activity in the membrane of Mycoplasma laidlawii. Biochim. Biophys. Res. Commun. 45:849-855.

5. Clarke, H. G. M., and T. A. Freeman. 1967. A quantitative electrophoretic method (Laurell electrophoresis), p. 503-509. In H. Peeters (ed.), Protides of the biological fluids, vol. 14. Elsevier, Amsterdam.

6. Deeb, B. J., and G. E. Kenny. 1967. Characterization of Mycoplasma pulmonis variants from rabbits. I. Identification and properties of isolates. J. Bacteriol. 93:1416-1424.

7. Deeb, B. J., and G. E. Kenny. 1967. Characterization of Mycoplasma pulmonis variants from rabbits. II. Basis for differentiation of antigenic subtypes. J. Bacteriol. 93:1425-1429.

8. Del Guidice, R. A., N. F. Robillard, and T. R. Carski. 1967. Immunofluorescence identification of $M y c o-$ plasma on agar by use of incident illumination. $\mathrm{J}$. Bacteriol. 93:1205-1209.

9. Edward, D. G. ff., and W. A. Fitzgerald. 1954. Inhibition of growth of pleuropneumonia-like organisms by antibody. J. Pathol. Bacteriol. 68:22-30.

10. Filip, C., G. Fletcher, J. L. Wulff, and C. F. Earhart. 1973. Solubilization of the cytoplasmic membrane of Escherichia coli by the ionic detergent sodium laurylsarcosinate. J. Bacteriol. 115:717-722.

11. Helenius, J. A., and K. Simons. 1972. The binding of 
detergents to lipophilic and hydrophilic proteins. J. Biol. Chem. 247:3656-3661.

12. Helenius, A., and K. Simons. 1975. Solubilization of membranes by detergents. Biochem. Biophys. Acta 415:29-79.

13. Hjertén, S., and K.-E. Johansson. 1972. Selective solubilization with Tween 20 of membrane proteins from Acholeplasma laidlawii. Biochim. Biophys. Acta 288:312-325.

14. Hollingdale, M. R., and R. M. Lemcke. 1972. Membrane antigens of Mycoplasma hominis. J. Hyg. 70:85-98.

15. Johansson, K.-E., I. Blomqvist, and S. Hjertén. 1975. Purification of membrane proteins from Acholeplasma laidlawii by agarose suspension electrophoresis in Tween 20 and polyacrylamide and dextran gel electrophoresis in detergent-free media. J. Biol. Chem. 250:2463-2469.

16. Johansson, K.-E., and S. Hjertén. 1974. Localization of the Tween 20 soluble membrane proteins of Acholeplasma laidlawii by crossed immunoelectrophoresis. J. Mol. Biol. 86:341-348.

17. Kenny, G. E. 1969. Serological comparison of ten glycolytic Mycoplasma species. J. Bacteriol. 98:1044-1055.

18. Kenny, G. E. 1973. Serological heterogeneity of the Mycoplasmatales. J. Infect. Dis. 127(Suppl.):52-55.

19. Laurell, C.-B. 1965. Antigen-antibody crossed electrophoresis. Anal. Biochem. 10:358-361.

20. Lemcke, R. M. 1965. A serological comparison of various species of Mycoplasma by an agar gel doublediffusion technique. J. Gen. Microbiol. 38:91-100.

21. Liljas, L., P. Lundahl, and S. Hjertén. 1974. Selective solubilization with Tween 20 of proteins from waterextracted human erythrocyte membranes. Analysis by gel electrophoresis in dodecylsulfate and in Tween 20. Biochim. Biophys. Acta 352:327-337.

22. Lowry, O. H., N. J. Rosebrough, A. L. Farr, and R. J. Randall. 1951. Protein measurement with the Folin phenol reagent. J. Biol. Chem. 193:265-275.

23. Makino, S., J. A. Reynolds, and C. Tanford. 1973. The binding of deoxycholate and Triton X-100 to proteins. J. Biol. Chem. 248:4926-4932.

24. Neimark, H. C. 1970 . Division of mycoplasmas into subgroups. J. Gen. Microbiol. 63:249-263.

25. Owen, P., and M. R. J. Salton. 1975. Antigenic and enzymatic architecture of Micrococcus lysodeikticus membranes established by crossed immunoelectrophoresis. Proc. Natl. Acad. Sci. U.S.A. 72:3711-3715.

26. Pollack, J. D., N. L. Somerson, and L. B. Senterfit.
1970. Isolation, characterization and immunogenicity of Mycoplasma pneumoniae membranes. Infect. Immun. 2:326-339.

27. Razin, S., M. Hasin, Z. Ne'eman, and S. Rottem. 1973. Isolation, chemical composition, and ultrastructural features of the cell membrane of the mycoplasma-like organism Spiroplasma citri. J. Bacteriol. 116:14211435.

28. Razin, S., H. J. Morowitz, and T. M. Terry. 1965. Membrane subunits of Mycoplasma laidlawii and their assembly to membranelike structures. Proc. Natl. Acad. Sci. U.S.A. 54:219-225.

29. Razin, S., and S. Rottem. 1967. Identification of Mycoplasma and other microorganisms by polyacrylamidegel electrophoresis of cell proteins. J. Bacteriol. 94:1807-1810.

30. Reynolds, J. A., and C. Tanford. 1970. The gross conformation of protein-sodium dodecyl sulfate complexes. J. Biol. Chem. 245:5161-5165.

31. Rottem, S., and S. Razin. 1967. Electrophoretic patterns of membrane proteins of Mycoplasma. J. Bacteriol. 94:359-364.

32. Senterfit, L. B., and K. E. Jensen. 1966. Antimetabolic antibodies to Mycoplasma pneumoniae measured by tetrazobium reduction inhibition. Proc. Soc. Exp. Biol. Med. 122:786-790.

33. Taylor-Robinson, D., O. Sobeslavsky, and R. M. Chanok. 1965. Relationship of Mycoplasma pneumoniae to other human species studied by gel diffusion. J. Bacteriol. 90:1432-1437.

34. Thirkill, C. E., and G. E. Kenny. 1974. Serological comparison of five arginine utilizing Mycoplasma species by two-dimensional immunoelectrophoresis. Infect. Immun. 10:624-632.

35. Tremblay, G. Y., M. J. Daniels, and M. Schaechter. 1969. Isolation of a cell membrane-DNA-nascent RNA complex from bacteria. J. Mol. Biol. 60:65-76.

36. Wróblewski, H. 1975. Dissolution sélective de protéines de la membrane de Spiroplasma citri par la désoxy. cholate de sodium. Biochimie 57:1095-1098.

37. Wróblewski, H., and D. Ratanasavanh. 1976. Etude par immunoélectrophorèse bidimensîonnelle de la composition antigénique de la membrane de quelques souches de mycoplasmes. Can. J. Microbiol. 22:10481053.

38. Yu, J., D. A. Fishman, and T. L. Steck. 1973. Selective solubilization of proteins and phospholipids from red blood cell membranes by nonionic detergents. J. Supramol. Struct. 1:233-248. 